\title{
交直並列送電連系が交流電圧安定性に及ぼす影響
}

\author{
正員多田泰之（東京電力） \\ 正員横山明彦 (東京大) \\ 正員関 根 泰 次 (東京大)
}

\section{The Influence of AC-DC Parallel Interconnection on \\ Voltage Stability of AC System}

Yasuyuki Tada, Member (TEPCO), Akihiko Yokoyama, Member, Yasuji Sekine, Member

(University of Tokyo)

In a contemporary bulk power system, the voltage instability phenomenon caused by insufficient power supply capability to load of constant power type is becoming an important problem. On the other hand, the increase of the short circuit capacity of power system is also becoming a serious problem, which may deteriorate the voltage stability.

In this paper, the static and dynamic characteristics of power supply to each load in hybrid AC-DC power system are analyzed by using static and transient $P-V$ curves respectively. In this analysis three kinds of DC transmission system control schemes are compared.

It is made clear that the DC transmission system has an advantage of increasing power supply capability at an inverter node. Also made clear is that constant firing angle-constant current control makes it possible to provide the inverter node with a larger power than the two conventional control methods, such as constant current-constant voltage control and constant power -constant extinction angle control methods. Transient digital simulations show that the DC interconnection improves the voltage stability under opening of $\mathrm{DC}$ inerconnected line or one-line opening of $\mathrm{AC}$ double-circuit interconnected lines.

キーワード：電力系統, 直流送電, 電圧安定度, $P-V$ 曲線

\section{1.はじめに}

直流送電はその特徵から，長距離大電力送電，海底 ケーブル送電，異周波連系，短絡容量抑制などの目的 で各国で適用されている。近年, 日本の電力系統は, 比較的短距離の送電線がループ構成をするに至り, 短 絡容量の增大が大きな問題になりつつある。更に、系 統の供給可能電力と負荷の要求電力の不均衝を主原因 とする電圧不安定現象が発生し, 負荷の特性, 系統の 供給能力の特性, の両画から精力的に研究が行われて いる(1)(2)(5)。

この電圧安定性を改善するためには, 系統の電力供 給能力を向上させることが必要で送電線設備を増強す
ればよいが，前述の短絡容量増大の問題が発生してし まう。送電線を增強せずに供給能力を向上させる方法 には，電力用コンデンサが有効であることがよく知ら れているが、これにも電力所敷地の制限, 低周波共振 の発生などの問題があるので限界がある。

本論文では, 直流送電には電力輸送中の無効電力損 失がないという点に注目し, 通常の交流系統に直流送 電線を付加することによる系統の電力供給能力の改善 効果を，モデル系統を用いて静的および動的な電力供 給特性を調べることによって基礎的な検討を行う。

\section{2. 静的供給電力特性の検討}

$\langle 2 \cdot 1\rangle$ 静的電圧安定性と静的 $P-V$ 曲線 電圧 
不定性は負荷の要求する有効, 無効電力を系統の電力 輸送設備の不備から満足に供給できない場合に発生す る。ここでは，負荷の動きに比較して系統の無効電力 制御が著しく速いとして, 直流送電を組込んだ電力系 統の電力供給特性を調べ，その結果を基に直流送電を 組込んだ電力系統の静的電圧安定性を議論する。その ために, 本論文では電力系統の供給最大電力および供 給電力と電圧の関係が明確になる静的 $P-V$ 曲線を利 用する。

\section{〈2・2〉 静的 $\boldsymbol{P}-\boldsymbol{V}$ 曲線の定義および計算手法}

静的 $P-V$ 曲線の定義は様々であるが，本論文では 交直変換器が消費する無効電力の静的電力供給特性へ の影響を明確にするため，次に示す定義を用いる。注 目ノードの静的 $P-V$ 曲線とは, 注目ノード以外のノ 一ドでは指定值（発電機ノードは $P, V$ 指定, 負荷） 一ドは $P, Q$ 指定）に固定すると共に，かつ注目ノ一 ドの無効電力 $Q$ を指定值に固定した状態で, 注目 一ドのPとVの関係を描いたものであるとする。

通常, 静的 $P-V$ 曲線は, 潮流多根計算法を用いて 描く。直流送電を含んでいる場合の潮流計算も，直流 系統の制御方式が変化しない領域では普通の潮流計算
法に若干の改良を加えることで行うことができる(3)。 しかし直流送電では, 電圧の大きさにより変換器制御 方式が変化するため，制御方式が切換わる動作点近傍 ではほとんど計算が収束しない。

そこで, 制御方式が切換わる動作点付近の静的 $P-$ $V$ 曲線を求めるために, 本論文では図 1 に示すよう な計算手法を考案し，これを基に静的 $P-V$ 曲線を描 くことにする。この計算手法の特徵は，アドミタンス 行列を用いて回路計算により直接ノード電圧を決定す ることにある。具体的には，注目ノードの等価コンダ クタンスを徐々に增加させ，注目ノードの消費電力を 徐々に大きくする。非注目負荷ノードでは一回の綠返 し計算中の電圧変化は大きくないとして（大きくなら ないように等洒コンダクタンスの增加を決定する)， $N$ 回目のノード電圧 $V_{k}^{(N)}$ と指定值 $P_{k}+j Q_{k}$ を用いて $(N+1)$ 回目の計算に用いる等価アドミタンス $Y_{k}^{(N+1)}$ を決定する。注目ノードの等価サセプタンスも同樣で ある。直流送電変換器等価アドミタンスの決定は, $N$ 回目の交直变換器ノード電圧 $V_{D C}^{(N)}$ と直流制御特性を 考慮し $(N+1)$ 回目の制御角 $\alpha^{(N+1)}$ および制御進み角 $\beta^{(N+1)}$ を決定し交直変換器の等価アドミタンスを計算

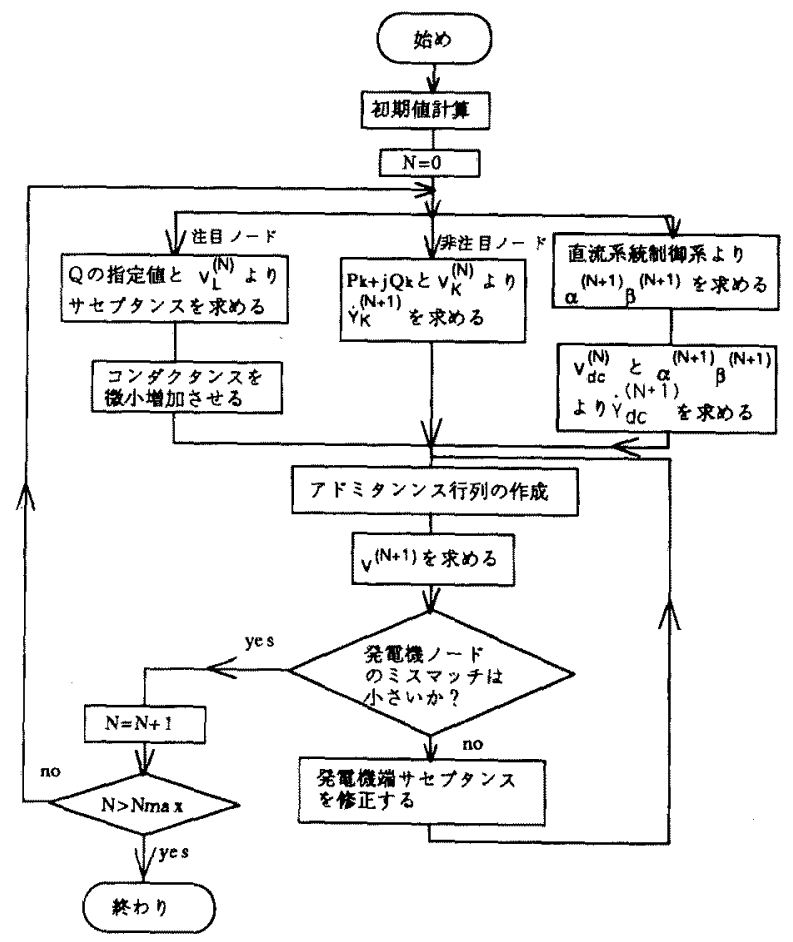

図 1 静的 $P-V$ 曲線の計算法

Fig. 1. Flowchart of static $P-V$ curve. 
する。一方，スイングノード以外の発電機ノードは, $P$ とVの指定值から等価コンダクタンスを決定し, 等価サセプタンスについては適当な初期值を与える。

各ノードの対地等価アドミタンスと系統のアドミタ ンス係数行列とスイングノードを用いて各ノード電圧 を計算し，各発電機ノードの電圧の大きさが指定值に 十分近ければ次のステップに, 偏差が大きい場合は, 発電機ノードの等価サセプタンスを調整し電圧の大き さが収束するまで計算を繰返す。この方法によれば， 直流送電変換器のように電圧により特性が変化する機 器を交流系統に組込んだ場合の静的 $P-V$ 曲線を容易 に求めることができる。

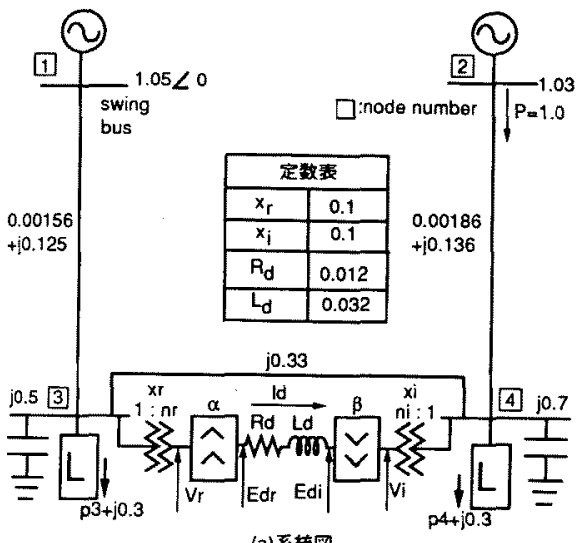

(a)系赫圆
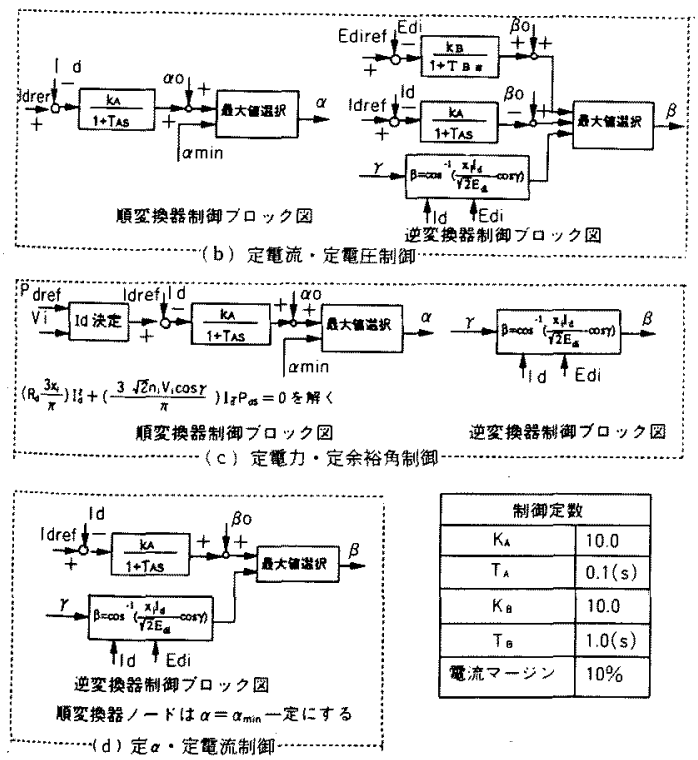

図 2 モデル系統

Fig. 2. Model system.
〈2・3〉 直流制御方式による静的 $\boldsymbol{P}-\boldsymbol{V}$ 曲線の比較

従来加らる定電流・定電圧制御, 定電力・定余裕 角制御の制御方式(6) と, 今回新たに提案する定遅れ制 御角 $(\alpha)$ ・定電流制御で制御を行う直流送電システム を，図2のモデル系統のように組込んだ場合と直流送 電システムを組込まない場合の静的電力供給特性を静 的 $P-V$ 曲線を比較することで検討する。ただし，交流 系統の諸定数, 負荷ノードの無効電力指定は図 2 (a) の系統図どおり，非注目負荷ノードの有効電力指定を $1.0 \mathrm{pu}$ とし，直流系制御設定值は表 1 に示す。

(1) 順変換器ノード

（i）変換器変圧器のタップを固定した場合 順

表 1 制御設定值

Table 1. Setting value of AC-DC converter.

\begin{tabular}{|c|c|c|}
\hline 制制方式 & 順交換器設定 & 逆変換器設定 \\
\hline 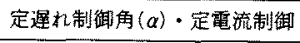 & $15^{\circ}$ & 0.9 \\
\hline 定電流・定電圧制御 & 0.9 & 1.0 \\
\hline 定電力・定余裕角 $(\gamma)$ 制御 & 0.9 & $25^{\circ}$ \\
\hline
\end{tabular}

$\gamma_{\min }=10^{\circ}, \quad a_{\min }=15^{\circ}$

制御設定値は最大電流が 0.9 pu 程度になるように決定した。

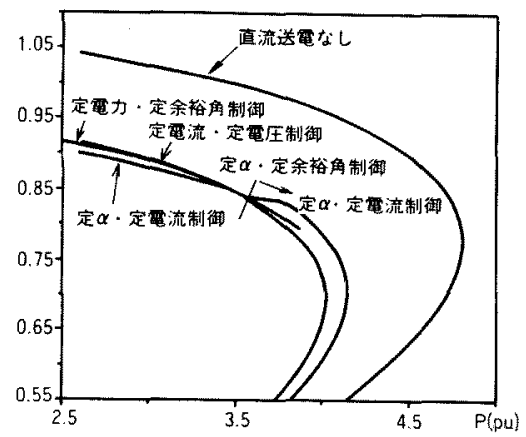

(a) 夕ッ>固定

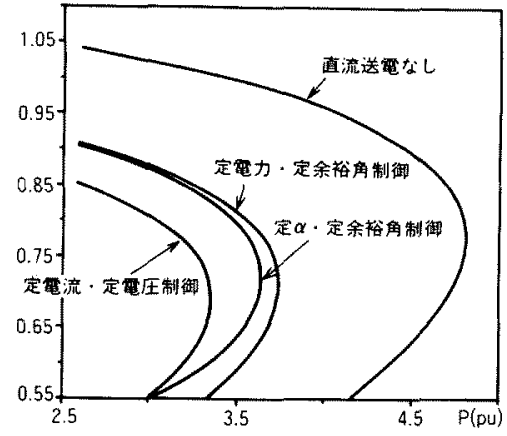

（b）タップ制御

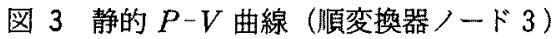

Fig. 3. Static $P-V$ curves (node 3 ). 
逆兩変換器変圧器のタップを 1.0 に固定した場合の静 的 $P-V$ 曲線を図 $3(\mathrm{a})$ に示す。直流系統がない場合 に比較して，直流系統がある埸合は直流送電をどの上 うに制御しても最大供給電力が小さくなってしまう。 つまり, 変換器無効電力消費による悪影響が現れてい る。また，定電流・定電圧制御，定電力・定余裕角制 御は電匡の低下に伴い制御方式が変化する。

(ii) 変換器変王器のタップを制御する場合 順 逆両変挨器変圧器のタップが無限に大きい調整幅をも つものとして, 交直変換器の入力電压が常に $1.0 \mathrm{pu}$ になるようにした場合の静的 $P-V$ 曲線が図 3 (b)で ある。この場合も，直流送電を組込むことにより最大 供給電力が隇少することには変わりがないが, 変換器 電圧の変化がないために直流送電の制御方式の移行は ない。また, 変換器での無効電力消費が少ない順に最 大供給電力が大きくなっている。

(2) 逆変操器ノード

（i）変換器変圧器のタップを固定した場合条 件は順変換器ノードと同じである。図 4 ( (a) に静的 $P-$ $V$ 曲線を示す。順変換器ノードと違い, 直流送電を

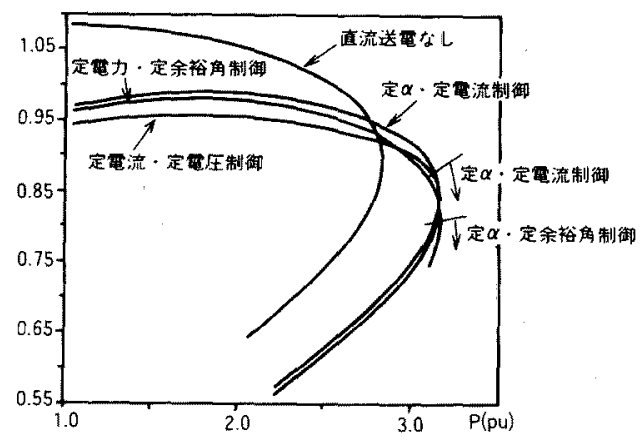

(a) タップ固定

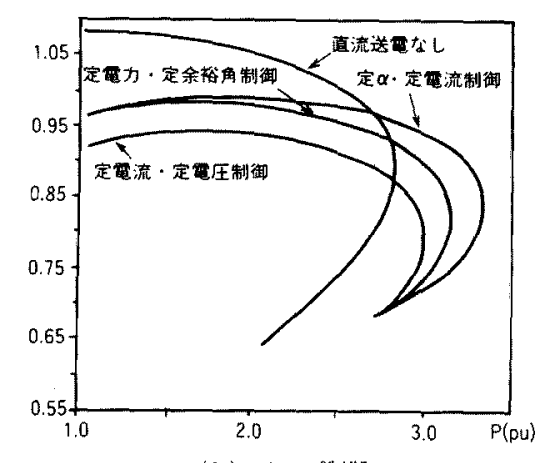

(b) タップ制御

図 4 静的 $P-V$ 曲線（这变換器） $-F^{*} 4$ )

Fig. 4. Static $P-V$ curves (node 4 ).
組込むことにより最大供給電力が大きくなる。この場 合も，定電流・定電圧制御，定電力・定余裕角制御て 電压の低下に伴い制御方式の移行が起こっている。順 変換器ノードの場合，直流送電を付加することで, 順 変換器での無効電力消費が大きく影響し, 直流送電に よる交流連系線の無効電力損失の低減の効果がなかつ たのに対し, 逆変換器側では交流連系線を輸送経路と しない有効電力が送られてくるために, 逆変換器の無 効電力消費增という悪影響があっても系統の供給能力 は增加する。また, 最大供給電力の制御方式による差 はほとんどないが,定 $\alpha$ ・定電流制街が,無効電力の消 費が少ないため，最も電圧を高く保つことができる。

更に, 直流送電が付加された場合の静的 $P-V$ 曲線 の供給電力の小さい部分での傾きが, 通常の $P-V$ 曲 線の場合と逆に正となり, 通常の $P-V$ 曲線下側部分 と同じになっている。この領域は, 直流送電によって 輸送された有効電力が逆変換器設置ノードで消費され るだけでなく，交流系統に流入するために現れる。こ の部分については，静的な解析だけては十分に検討で きないので動的解析を行うときにも触れる。

(ii) 変換器変压器のタップを制御する場合 図 4 (b)に静的 $P-V$ 曲線を示す。直流送電による最大 供給電力の增加がここにも明確に出ているが, タップ を固定したときとは違い, 制御方式により最大供給電 力に差が現れ，タップ制御なしのときと比較すると定 電力・定余裕角制御では最大供給電力はほとんど変化 せず，定電流・定電圧制御では減少し，定 $\alpha \cdot$ 定電流制 御方式では增加している。これは, 両変換器の無効電 力消費むよび直流送電電力の関係から説明される。

定電力・定余裕角制御は両変换制御器での無効電力 の消費が，他の制御方式に比較して少なく，かつ雨変 换器入力電圧の大きさに対して無効電力消費の変化の 割合が小さい。また，直流送電電力が一定であるため 系統の最大供給電力は夕ップ制衙にほとんど影響され ない。一方, 定電流・定電圧制御は変換器入力電压の 降下に伴い両変換器での無効電力の消費が減少すると いう性質がある。そのため, 変換器入力電圧を一定に するタップ制御を行うと, 無効電力消費の減少が現れ なくなり，最大供給電力は減少する。定 $\alpha$ ・定電流制 御方式も逆変換器入力電圧の降下に伴い無效電力消費 が減少するがその量はわずかであり，逆に順変换器入 力電圧の降下に伴い直流送電電力が減少してしまう。 そのため, 変換器入力電圧を一定にするタップ操作を 行うことにより直流送電電力の翰送量の低減を防ぐこ とができ最大供給電力が増加するのである。

$\langle 2 \cdot 4\rangle$ 静的に見て有利な制御方式 〈2・3〉節で得 


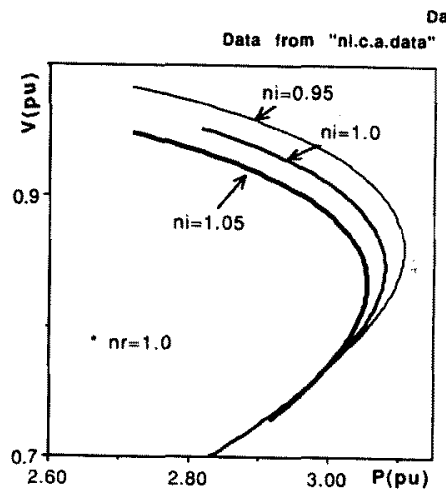

(a) 順率器タップパラメータ

trom "nr.c.a.data"

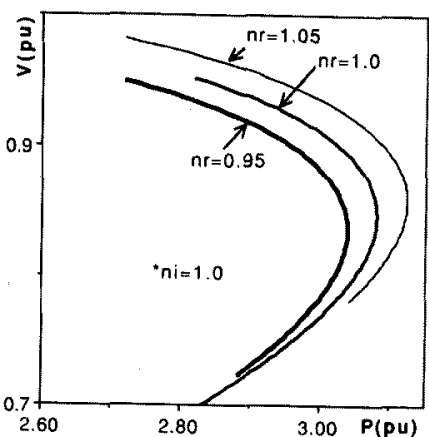

(b) 逆变揬夕ップパラメータ

図 5 タップ值をパラメータとした静的 $P-V$ 曲線

Fig. 5. Static $P-V$ curves with different tap values.

られた結果は, 順変換器設置ノードの電力消費が比較 的一定で, 逆変換器設置ノードの電力消費が大きくな るような場合には，系統全体の静的供給電力を短絡容 量の增加なしに改善できることを意味する。そこで, 系統全体の静的電力供給特性を最も良く改善できる直 流送電制御方式を逆変換器設置ノードの電力供給特性 改善という視点から，図 4(a)，(b)を用いて検討す る。

最大供給電力は, タップを固定した場合, わずかな がら，定 $\alpha$ ・定電流制㼋が最も大きく，タップを制衔 したときは明らかに定 $\alpha \cdot$ 定電流制御が大きい。また, 供給電力に対する電圧の大きさも定 $\alpha$ ・定電流が大き い。從って, 本論文で取上げた茞流送電制御方式で は, 定 $\alpha$ ・定電流制御が静的電力供給特性を最も向上 させるということがてきる。

更に, 変圧器のタップが有限であることを考慮し, 定 $\alpha \cdot$ 定電流制御を最も有効に活用できるタップ設定 值を計算したのが図 5 である。罒より明らかなよう に, 順変換器ではタップを大きくし, 逆変換器では小 さくすると電力供給特性が改善されている。これは， 次のように説明される。順変換器入力電圧を大きくす ることにより順変換器直流電圧が大きくなり, 逆変換 器では直流電流を設定值に保つため直流電圧を大きく しなければならない。そのために，逆変換器では進み 制御觕が小さくなり逆変換器の無効電力消費は減少す る。また, 進み制御角を小さくすることは，逆変換器 入力電圧を小さくしても契現される。このように，無 効電力消費がタップを操作することにより減少するの でタップ操作で最大供給電力が改善できる。更に， 順変換器入力電圧を高くすることは，直流送電電力を 大きくする効果もあるので最大供給電力を合せて改善
する。図5の結果は以上の効果によるものである。

\section{3. 動的電力供給特性の検討}

〈3.1〉 過渡 $\boldsymbol{P}-\boldsymbol{V}$ 曲線 動的電圧安定性を検討 するために，動的電力供給特性を調べる過渡 $P-V$ 曲 線(4) 導入する。本論文でいう注目ノードの過渡 $P$ $V$ 曲線は，非注目ノードの $P, Q$ を指定值に固定，ス イングノード以外の発電機ノードは $P, V$ 指定值に固 定した状態で注目ノードにある負荷モデルを接続し， じょう乱を起こした後の $P$ と $V$ の軌跡を描いたもの とする。この曲線によって，系統の動きに対して負荷 の動きが速い場合の系統の供給特性が得られる。

負荷モデルには動的電圧安定性にとって過酷な図 6 の簡易誘導電動機モデルを用いる。この負荷モデルの 過渡 $P-V$ 曲線㰞次のようになる。いま，負荷が図 7

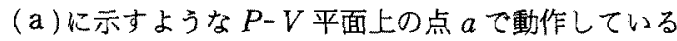
とする。この動作点は, 負荷の要求する機械出力 $P_{m}$ と誘導電動機の滑り一定の $P-V$ 曲線の交点に相当す る。この動作点の無効電力を一定にした状態で消費電 力を大きくし系統の $P-V$ 軌跡を描いたのが，静的 $P$ - V曲線である。しかし，実際の負荷の軌跡は無効電 力消費が一定でなく，消費電力の增加に伴い增加する ために，図7(b)のように，負荷要求電力の増加に伴 い運転点が点 $b$ に移動する。

ところて，誘導機の滑り一定の $P-V$ 曲線は滑りが 小さいうちは，滑りが大きくなるにつれて傾きが小さ く,つまり時計方向に回転するが，負荷の滑り $s か ゙$ $r / s=x$ の条件を満たす滑りsより大きくなると逆に 傾きが大きく，つまり反時計方向に戻ってくる。以上 のことより, 負荷の過渡 $P-V$ 曲線の最大供給電力は 図 7 (c)に示すように静的 $P-V$ 曲線のものよりも小 


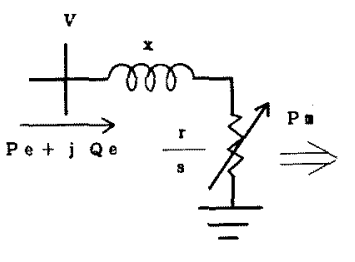

$$
\begin{aligned}
& P_{e}=\frac{r / s}{(r / s)^{2}+x^{2}} v^{2} \\
& Q_{\theta}=\frac{x}{(r / s)^{2}+x^{2}} v^{2} \\
& \frac{d s}{d t}=\frac{1}{I w_{0}^{2}}\left(\frac{P R}{1-s}-P_{\theta}\right)
\end{aligned}
$$

図 6 負荷モデル

Fig. 6. Load model.

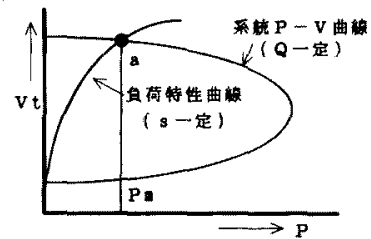

（a）動作点の決定

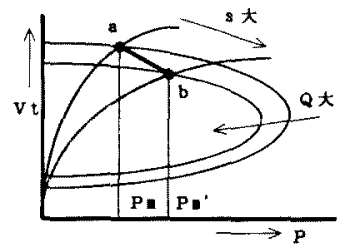

（b）動作点の移動

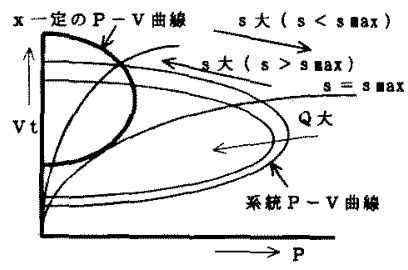

（C）各 $P-V$ 曲線の関倸

図 7 過渡 $P-V$ 曲線の概念

Fig. 7. Concept of transient $P-V$ curve.
さくなる。つまり，静的 $P-V$ 曲線が消費無効電力の 一定の $P-V$ 曲線であったのに対し，本論文の負荷モ

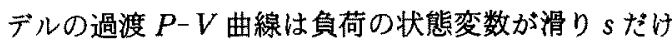
であることから，リアクタンス $x$ 一定の $P-V$ 曲線に なる。

別の見方をすれば，系統の無効電力補償が負荷の無 効電力消費の変化に十分対応できる場合は, 系統から 見たとき負荷ノードは，定無効電力消費ノードと見る ことでき，静的 $P-V$ 曲線の軌跡上を運転点が移動し ていくと考えられるが，賏荷の動きが早く無効電力補 償がほとんど行えないような状態では，ほ㴽過渡 $P$ $V$ 曲線上を動き供給可能電力が小さくなることが推 測される。この過渡 $P-V$ 曲線を比較することによ り，系統が動きの早い負荷に対して，どの程度対応で きるかを知る目安になる。

過渡 $P-V$ 曲線の最大電力は, 系統の供給能力に影 響を受けることはもとより，誘導電動機負荷モデルの リアクタンスに大きく左右される。本論文の負荷モデ ルの場合は誘道電動機の比例推移の関係により，系統 側を無限大母線とすれば，最大消費電力は誘導電動機 負荷モデルのリアクタンス $x$ により決定され，抵抗 はその最大消費電力を発生する滑りを決定するのみて ある。そこで, 本論文の過渡 $P-V$ 曲線初期値計算時 には $P, Q$ 指定でなく,$P$ とリアクタンス $x$ を指定し て計算を行っている。

\section{〈3.2〉各種制御方式の過渡解析}

（1）負荷要求電力急增の場合 図 8（a）に負荷 要求電力が急增した場合の, 逆変換器ノードの過渡 $P-V$ 曲線を示す。条件は, 誘導機負荷モデルのリア

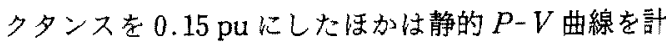
算したときと同じである。タップは初期值計算時に変 換器入力電圧が $1.0 \mathrm{pu}$ になるようにし，その後㹥変 化しないものとしている。この場合は交流系統が最も

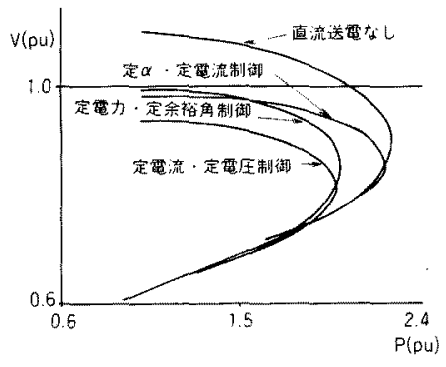

(a) $n_{\tau}=n_{i}=1.0$

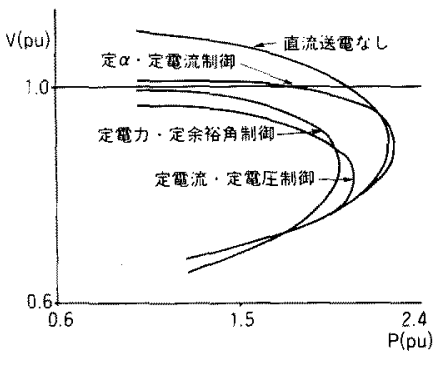

(b) $n_{r}=1.05, n_{i}=0.95$

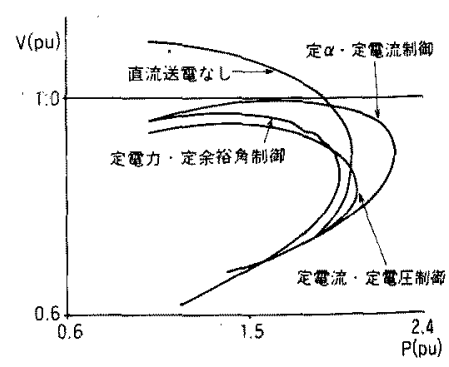

(c) 交流連系線 1 回線開放

図 8 過渡 $P-V$ 曲線

Fig. 8. Transient $P-V$ curves. 
有利である。しかし，定 $\alpha$ ・定電流制御のタップを図 5 で得られた静的に有利な条件に設定し初期値計算を 行い, 過渡 $P-V$ 曲線を描くと図 8 (b)のようになり 定 $\alpha$ ・定電流制御が有利になる。また, 交流連系線 1 回線開放を意味する交流連系線のアドミタンスを半分 にし，かつ，(b)図と同じタップ条件で過渡 $P-V$ 曲 線を描くと(c)図のようになり, 各直流送電線を含ん だ場合の動的最大供給電力がほとんど変化しないのに 対して, 直流系統を含まない場合は大きく減少する。

更に，ノード消費電力が小さく静的 $P-V$ 曲線の傾 きが通常とは逆の領域で過渡 $P-V$ 曲線の傾きも逆に なっている。これは, 系統の静特性が逆の傾きをもっ ているためである。しかし, 過渡 $P-V$ 曲線の傾きが 逆でも, 電圧不安定であるとは言いきれない。なぜな ら,この過渡 $P-V$ 曲線は負荷の動きを系統から見た 場合にどのような軌跡をとるかを示しているだけで， 負荷の要求トルクと系統の供給電力の差を直接表して はいない。つまり，静的あるいは動的の $P-V$ 曲線か ら安定性を論じるには注意が必要である。

（2）交流連系線の一回線開放によるじょう乱が加 えられた場合直流送電線を付加した系統が交流連 系線のアドミタンスの変化に対して強いことを交流連 系線の一回線開放時のシミュレーションで示す。条件

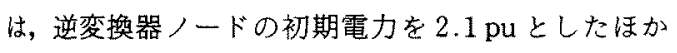
は(1)項のとおりである。定 $\alpha \cdot$ 定電流制御（タップ が最も有利な状態) の制御特性をもつ直流送電システ 么を付加した場合と, 直流送電システムを付加しない 場合の交流連系線 1 回線開放時の動きをシミュレーシ ヨンしたのが図 9(a)，(b)である。交流連系のみの 場合は崩壊してしまっているが, 直流送電がある場合 には系統への影響はほとんどない。これは，前述のよ うに直流送電を含んだ系統では, 動的な供給能力が活 とんど変化しないということより説明できる。なお， 交流連系線を変化させずに直流送電線が開放された場 合のシミュレーションを(c)図に示す。直流送電線が 開放されても急荷の運転を妨げるような電圧崩壊には 至っていない。以上のことより, 直流送電線を系統に 組込むことにより，動的供給能力を著しく改善しない までも外的なじょう乱に対する耐力を強くすることが きるといえる。

\section{4. 終りに}

本論文では, 電圧安定度を改善するという観点から 線路の無効電力損失がないという植流送電の利点を生 かして, 系統の短絡容量を増大させずに系統の供給可 能電力を增加させることを検討した。検討の結果, 直

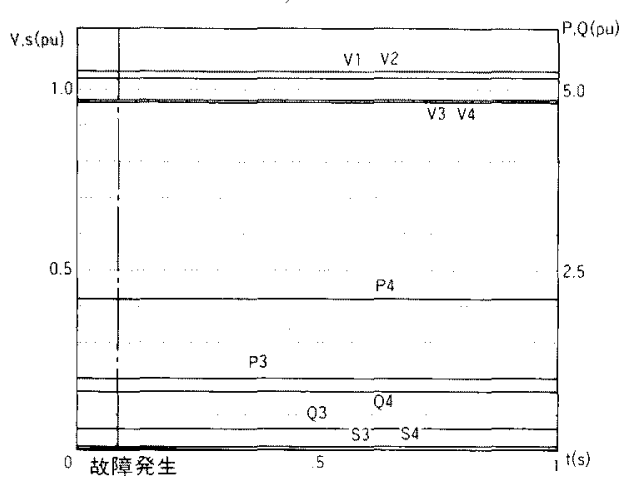

（a）交流連系線 1 回線開放（值流送電あり）

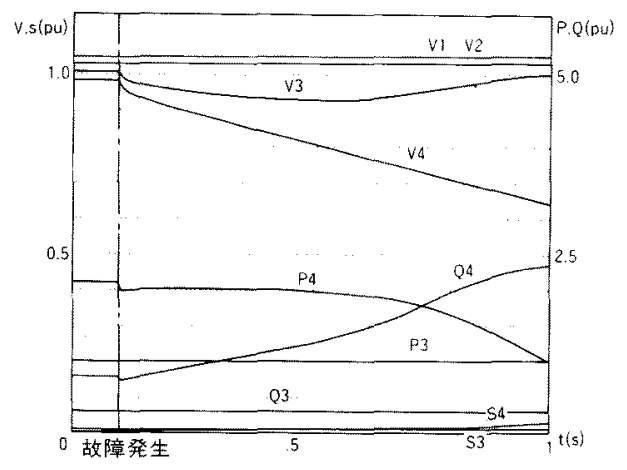

(b) 交流捙系線 1 回線開放（真流送電なし）

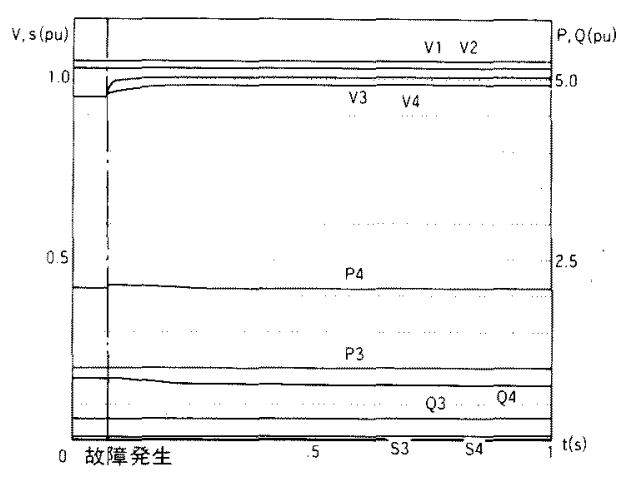

(c) 直流送雪開放

図 9 過渡シミュレーション結果

Fig. 9. Transient simulations.

流送電線を付加することにより, 順変換器設置ノード では直流交換器の無効電力消費が悪影響を及ぼすが, 逆变換器設置ノードでは短絡容量の増加, 動的供給能 力の低下を発生することなく, 静的供給能力, 交流連 系線 1 回線開放の上うな大じょう乱後の過渡供給可能 電力の向上が可能であることがわかった。今後, 定 $\alpha$ ・定電流制御方式について従来の同期安定度との関 
係や直流送電電圧への影響を詳細に検討する必要があ ろう。 (平成 2 年 11 月 19 日受付) 文献

(1) Y. Sekine, A. Yokoyama: "MULTI SOLUTIONS FOR LOAD FLOW PROBLEM OF POWER SYSTEM AND THEIR PHYSICAL STABILITY", 7th PSCC Proc., p. 819 (1981)

(2) H. Ohtsuki \& Y. Sekine: "CASCADED VYLTAGE COLLAPSE", 89SM 210-5-PWRS at IEEE/PES summer meeting, Long Beach, (1989)

（3）林他:「交直連系系統の潮流計算手法の開発」, 電中研報, No. 73068

(4) H. Ohtsuki, A. Yokoyama \& Y. Sekine: “TRANSIENT $P-V$ CURVES USED FOR THE ANALYSIS OF TRAN SIENT VOLTAGE STABILITY", 10th PSCC Proc. p. 1202-1209, 1990

（5）小島, 他：「系統負荷特性のモデル研究」, 電気学会電力技 術研資会 PE-89-8（平元）

（6）町田：直流送電（東京電機大学出版）

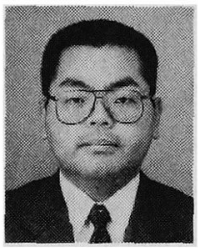

\section{多田泰之（正員）}

昭和 38 年 3 月 20 日生。 56 年 3 月埼玉県立川越工業電気科卒業。同 年 4 月東京電力(株)入社。63 年東 電学園大学部卒業。平成元年 4 月よ り, 同社技術研究所系統研究室で電力系統の研究, 解 析業務に從事。この間, 平成元年 4 月より 1 年間東京 大学工学部電気工学科受託研究長。

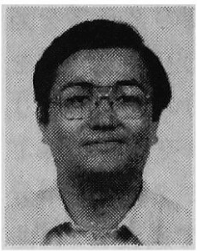

\section{横 山 明 彦（正員）}

昭和 31 年 10 月 9 日生。 59 年 3 月東京大学大学院工学系研究科電気 工学専門課程博士課程修了。工学博 士。同年 4 月東京大学工学部電気工 学科助手, 60 年同講師, 平成元年同助教授, 現在 至る。主として, 電カシステム工学の研究に従事。日 本応用数理学会, IEEE, CIGRE 会員。

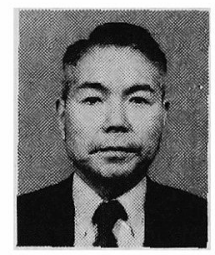

\section{関 根 泰 次 (正員)}

昭和 6 年 12 月 7 日生。 34 年 3 月 東京大学大学院数物系研究科博士課 程修了。同年 4 月同大学工学部電気 工学科講師, 35 年同助教授, 47 年 同教授。工学博士。主として, 電力系統工学および系統 工学の研究に従事。35 年度, 45,50 年度, および 62 年度電気学会論文賞, 43 年度および 47 年度電気学会 著作賞, 49 年度電気学会電力賞受賞。河上・倉田各研 究奨励金受賞。47 48 年度電気学会編修理事, $58 \sim 59$ 年度同副会長, 平成元年度同会長。PSCC 会 長, CIGRE 国内委員会委員長, IEEE Fellow, 日本工 学アカデミー会員。 